\title{
PROGRESSION OF BARRIER ISLAND RESTORATION IN LOUISIANA
}

\author{
Jason Lanclos, Coastal Protection and Restoration Authority, Jason.Lanclos@la.gov \\ Brett Borne, Coastal Engineering Consultants, Inc., bborne@ceci-la.com \\ Michael Poff, Coastal Engineering Consultants, Inc., mpoff@cecifl.com
}

\section{INTRODUCTION}

Over the last several decades restoration efforts in coastal Louisiana have evolved from efforts known mostly to State and Parish officials and academic community to national recognition in the wake of Hurricanes Katrina and Rita and the Deepwater Horizon Oil Spill. Consolidated efforts of coastal restoration developed in the early years through the Coastal Wetlands Planning, Protection, and Restoration Act (CWPPRA). Additional funding and organizational efforts include State funding; the Coastal Impact Assessment Program (CIAP); and most recently from programs resulting from Deepwater Horizon Oil Spill penalties.

\section{BARRIER ISLAND RESTORATION HISTORY}

The initial barrier island restoration projects in Louisiana were funded through CWPPRA and targeted one or two island features with restored hectares in the mid to upper 80 's. Present day efforts under the new programs restore complete island habitats exceeding 200 hectares (CPRA, 2017). Through lessons learned during construction; post-construction monitoring; and more robust geophysical, geologic, and geotechnical investigations; restoration designs are now developed with a more thorough understanding of subsidence and compaction, alongshore and cross shore sediment transport, and storm erosion losses. The goal of current restoration designs is primarily to restore the island's geomorphic and ecological form and function (GEFF) (Poff and Stephen, 2012).

\section{LIMITED SAND RESOURCES}

As more projects have been constructed in an effort to stem the coastal land loss issues of Louisiana, the nearshore relict channel borrow sources previously used for restoration are becoming exhausted which has led project teams to utilize sediments further offshore from historical deltaic shoals or the Mississippi River. Whereas the early project borrow areas were adjacent to or within a few miles of the restoration areas, current project borrow areas now require pipeline distances of greater than 32 kilometers and in the case of hopper dredge or scow transport, greater than 55 kilometers.

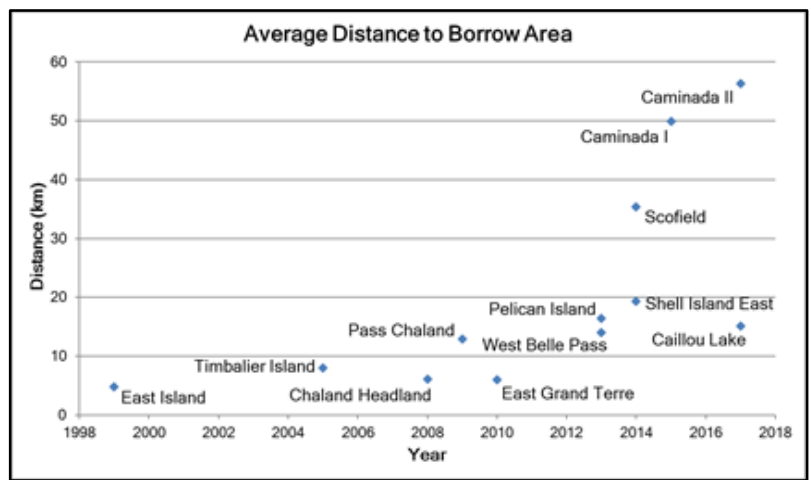

Figure 1 - Trends in Distance Between Borrow Areas and Restoration Areas Over the Past Two Decades

\section{ISLAND RESTORATION COSTS}

With the increase in distance between the barrier island restoration areas and borrow areas, projects have seen a subsequent increase in construction costs. Early projects such as the East Island Restoration Project cost less than $\$ 5$ USD per cubic meter of sediment as the borrow area was located approximately $5 \mathrm{~km}$ from the restoration area in nearshore waters (TBS, 1998). In 2017 the Caminada Headland Beach and Dune Restoration Project was built at a cost of approximately \$35 USD per cubic meter of beach sediment (CEC, 2016). Furthermore, hopper dredges and scow barges were utilized to transport fill material over $55 \mathrm{~km}$ from the borrow area to the restoration area for this project.

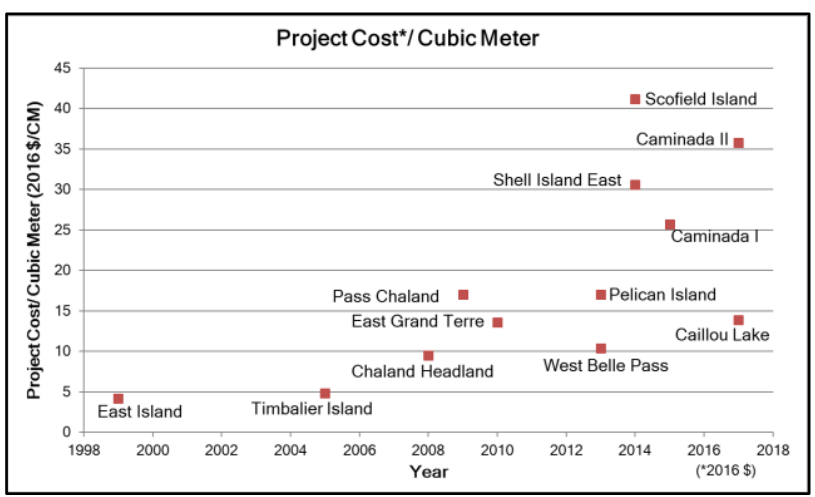

Figure 2 - Trends in Barrier Island Restoration Project Costs Over the Past Two Decades

\section{CONCLUSION}

Advancements in restoration have resulted in increased longevity through the creation of robust marsh habitats as well as beach and dune features to restore the GEFF of barrier islands. Consequently, barrier island restoration projects have increased in size, scope, and construction cost over the past 20 years. Limited availability of nearshore borrow areas with adequate volumes of beach compatible sand has resulted in utilizing borrow areas located farther away from the restoration areas.

\section{REFERENCES}

Coastal Protection and Restoration Authority of Louisiana (2017): Louisiana's Comprehensive Master Plan for a Sustainable Coast.

Coastal Engineering Consultants (2016): Caminada Headland Beach and Dune Restoration - Increment II (BA-143) Completion Report.

Poff and Stephen (2012): Design Premises for Barrier Island Ecosystem Restoration in Louisiana. Proceedings of the $33^{\text {rd }}$ International Conference on Coastal Engineering.

T. Baker Smith and Son (1998): Isle Dernieres Restoration Projects - East Island As-Built Drawings. 